\title{
站送用ローラーにおけるセラミックス赀スリーブの焼外しが可能となる条吽の検討
}

\section{Analysis of Separation Conditions for Shrink Fitting System Used for}

\section{Ceramics Conveying Rollers}

\author{
$\bigcirc$ 非 栗 文涁（九工大）学 酒井 悠正（九工大） \\ 正 野田 尚昭（九工大） 正 高瀬 康 (九工大)
}

\begin{abstract}
Wenbin Li, Kyushu Institute of Technology, Sensui-Cho 1-1 Tobata-Ku, Kitakyushu-Shi, Fukuoka
Hiromasa Sakai, Kyushu Institute of Technology, Nao-Aki NODA, Kyushu Institute of Technology

Yasushi TAKASE, Kyushu Institute of Technology
\end{abstract}

Key words : Ceramics, Boundary condition, Finite Element Method, Contact, Separation time, Heating

\section{1. 粕 吾}

圧延工場における鋼板搬送用ローラー(図 1 参照)には, 合金 鋳鉄, 炭素鋼や合金鋼が使用されており, 使用条件によっては, 比較的早期にローラー表面の摩耗・肌荒れが生じる場合がある.

そこで, 著者らは, 図 2(a)のように胴部をスリーブ化し, そのスリ 一ブ材料を耐熱性・耐摩耗性に優れるセラミックスとし (1), 軸部を その両端に, 従来の溶接接合ではなく焼嵌め接合する構造に着 目した.著者らは先に,この構造で接合部に生じる応力に関して幾 何的条件を変えて考察し, 様々な結果を得た ${ }^{(2)}$.

一方で, 軸部には鋼を用いるため, セラミックスに比べて寿命が 短いことや, 軸受部での摩耗や疲労, 周辺環境における腐食など により定期的な交換が必要となる.その際, セラミックス製スリーブ を外側から加熱しながら軸部を冷却することによる焼外しによって 分解し, 別の軸と交換を行うことが望ましいが，鋼はセラミックスよ り線膨張率が約 5 倍大きいためセラミックス製スリーブに比べて, 加熱による膨張が大きいので外側から加熱しても焼外しがかなり 困難となる.

そこで本研究では，図 2(a)の構造の軸部に冷却のための穴を 開けた図 2(b)の構造に注目する. そして, 軸部材料を鋼, スリーブ 材料をセラミックスとした場合における焼外しが可能となる条件等 を, 幾何的条件を変更していきながら有限要素法を用いた解析に より検討する.

\section{2. 解析条件}

2. 1 境界条件 焼嵌め代 $\delta$ をスリーブ嵌め込み部の内径 $\mathrm{d}$ $=210 \mathrm{~mm}$ で除したものを焼嵌め率 $\delta / \mathrm{d}$ と定義する. 初めに図 3 に 示す初期形状を焼嵌め率を変えて解析する. その後, 嵌めこみ 長さ L 等の幾何的条件を変化させ, それぞれの形状で焼嵌め率 $\delta / \mathrm{d}$ の影響を調べる. 加熱時間は $10000 \mathrm{~s}$ とし, 加熱箇所はスリー ブ部と軸部の接触箇所のスリーブ部外表面とする(図 3(b) 及び 図 4 参照).水冷箇所は軸部内表面とする. 空冷箘所はスリーブ

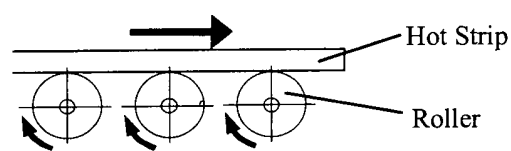

Fig.1 Layout of Conveying Rollers

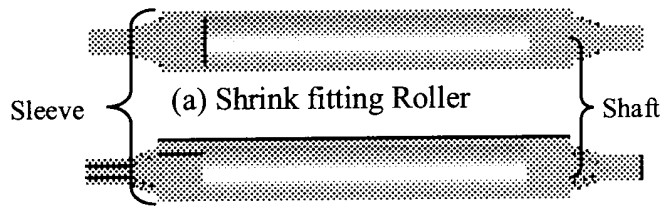

(b) New Shrink fitting Roller Fig.2 Roller Structure
部外表面, 内表面, 右端面及び軸部外表面, 左端面とする. 対流 に関しては加熱及び水冷では強制対流, 空冷では自然対流とす る(図 3(b) 参照). また, 本解析では軸対称モデルを用いているた めスリーブ部左端面は断熱及び軸方向変位 $\mathrm{u}_{\mathrm{z}}=0$, せん断応力 $\tau_{\mathrm{rz}}=0$ である. 接触面での伝熱形態としては主に実接触面の固体 熱伝導と接触面の隙間に介在する流体を通しての熱伝導である

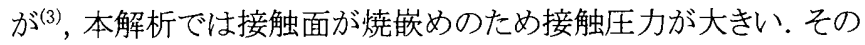
ため固体熱伝導が支配的となり，接触熱伝達率 C の值が非常に 大きくなる.よってその值を $1.0 \times 10^{9} \mathrm{~W} / \mathrm{m}^{2} \cdot \mathrm{K}$ とする.

2.2 各材料の物性值 表 1 にローラーの材料の物性值を示 す.軸部の材料恃常に鋼のままであるが, スリーブ部の材料として は, セラミックス $\mathrm{A}$ とセラミックス $\mathrm{B}$ の 2 種類のセラミックスを考える. 2 種類のセラミックスの大きな違いは熱伝導率であり, セラミックス A はセラミックス B に比べて常温で 4 倍弱熱伝導率が大きい.この ような性質は熱応力の低減に極めて有効であるが, 反面メンテナ ンス時に分離するのが困難となる。

2. 3 解析モデル セラミックスはほとんど塑性変形を生じないこ とから, 解析は軸対称弾性解析とする. 四辺形軸対称要素を使用 し, 初期形状は, 要素数 3760 , 節点数 4347 である.モデルは対称 性を考慮し, 全体の $1 / 2$ を対象としている。

\section{3. 解析結果及び考察}

本研究では, スリーブ部と軸部の接触面の分離時間に注目をし, 異なる材料や寸法を用いて解析を行った。

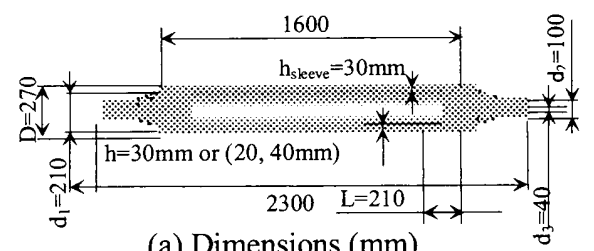

(a) Dimensions (mm) Air cool Heat $\left(\alpha=5.0 \times 10^{-5}\left(\mathrm{~W} / \mathrm{m}^{2} \cdot \mathrm{K}\right), \varepsilon=0\right) \quad\left(\alpha=5.0 \times 10^{-5}\left(\mathrm{~W} / \mathrm{m}^{2} \cdot \mathrm{K}\right), \varepsilon=0.4\right)$

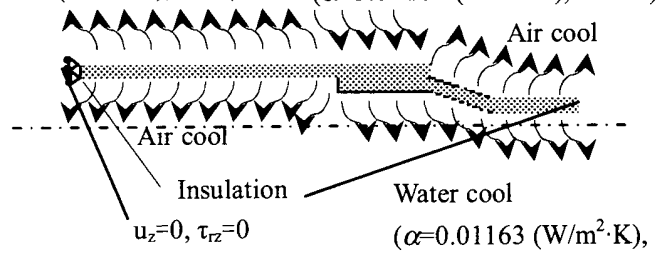

$\varepsilon=0$ )

(b) Boundary condition Fig.3 Models A 


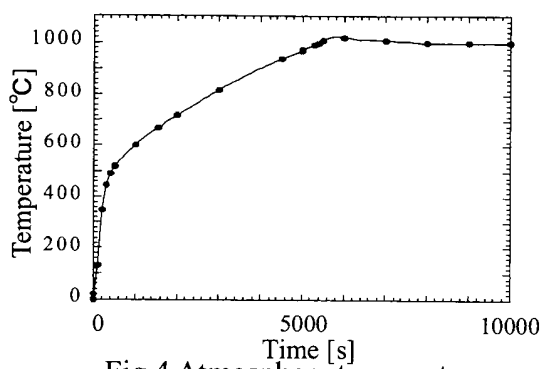

Fig.4 Atmosphere temperature

Table2 Material properties

\begin{tabular}{c|c|c|c}
\hline \hline & $\begin{array}{c}\text { Ceramics } \\
\text { A }\end{array}$ & $\begin{array}{c}\text { Ceramics } \\
\text { B }\end{array}$ & $\begin{array}{c}\text { Steel } \\
\text { (HV200) }\end{array}$ \\
\hline $\begin{array}{c}\text { Young's modulus } \\
{[\mathrm{MPa}]}\end{array}$ & 300 & 294 & 210 \\
\hline Poisson's ratio & 0.28 & 0.27 & 0.3 \\
\hline $\begin{array}{c}\text { Tensile strength } \\
{[\mathrm{MPa}]}\end{array}$ & 500 & 500 & 600 \\
\hline $\begin{array}{c}\text { Mass density } \\
{\left[\mathrm{kg} / \mathrm{m}^{3}\right]}\end{array}$ & 3200 & 3260 & 7800 \\
\hline $\begin{array}{c}\text { Thermal conductivity } \\
{[\mathrm{W} / \mathrm{m} \cdot \mathrm{K}]}\end{array}$ & $62.5(393 \mathrm{~K})$ & $17(393 \mathrm{~K})$ & 25 \\
\hline $\begin{array}{c}\text { Thermal expansion } \\
\text { Coefficient [1/K] }\end{array}$ & $3.0 \times 10^{-6}$ & $3.0 \times 10^{-6}$ & $1.45 \times 10^{-5}$ \\
\hline $\begin{array}{c}\text { Specific heat } \\
{[\mathrm{J} / \mathrm{kg} \cdot \mathrm{K}]}\end{array}$ & 680 & 650 & 477 \\
\hline $\begin{array}{c}\text { Emissivity } \\
\text { (12.5 }\end{array}$ & 0.4 & 0.4 & 0.4 \\
\hline
\end{tabular}

以下に示す分離時間とはすべての接触面の分離が終了した 時間を表している.

図 5 は嵌め込み長さ $\mathrm{L}$ の分離時間に対寸る影響である. 加熱 部は Lを変えても一定にしている. 焼嵌め率 $\delta / \mathrm{d} \geqq 0.08 \times 10^{-4}$ の範 囲で分離時間が最も長いのは $\mathrm{L}=210$ の場合であり, 最も短いの は $\mathrm{L}=140 \mathrm{~mm}$ の場合である.これは嵌め込み長さ Lを変化させる ことで水冷の長さが変化するためである. しかし $\mathrm{L}<180 \mathrm{~mm}$ になる と分離時間にそれほど差は見られない. また $\delta / \mathrm{d}<0.08 \times 10^{-4}$ の範 囲では $\mathrm{L}=100 \mathrm{~mm}$ から $\mathrm{L}=210 \mathrm{~mm}$ まで分離時間に大きな差はな い.

図 6 は嵌め込み部厚さ $\mathrm{h}$ の分離時間に対する影響である. $\mathrm{h} か ゙$ 大きくなると分離時間は長くなる.嵌め込み部厚さ $\mathrm{h}$ の大きい $\mathrm{h}=40 \mathrm{~mm}$ では, 軸部内部の泠却効果が小さくなるので分離しにく $<$, 分離時間が長くなる.

図 7 はスリーブ部外径 D の分離時間に対する影響である. D が 大きいと分離時間は短くなる.これはスリーブ部外径 $\mathrm{D}$ が大きくな ると軸部に伝わる単位面積当たりの熱が小さくなるため軸部の膨 張が抑えられスリーブ部と分離し易いためである.

図8はスリーブ部材料の分離時間に対する影響である. セラミッ クスAの熱伝導率は常温でセラミックス $\mathrm{B}$ の倍あるため, スリーブ 部の材料はセラミックス A の方がセラミックス B の場合より分離時 間は長い. スリーブ部に使用する材料の熱伝導率が大きいと温度 が上昇しにいため膨張に時間がかかる。

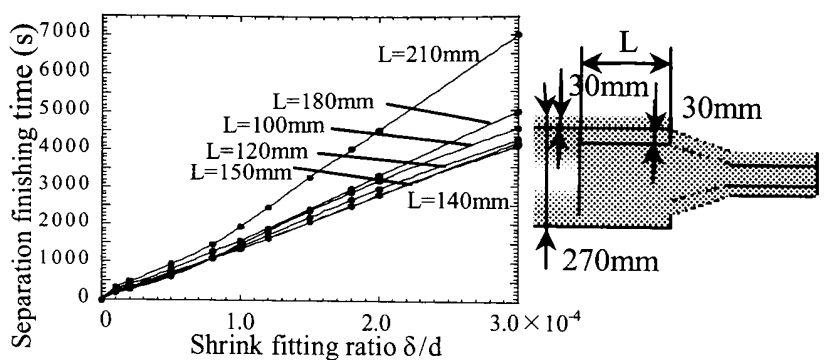

Fig. 5 Time vs. $\delta / \mathrm{d}$ when $\mathrm{L}=100 \mathrm{~mm}, 120 \mathrm{~mm}, 140 \mathrm{~mm}$, $150 \mathrm{~mm}, 180 \mathrm{~mm}, 210 \mathrm{~mm}$

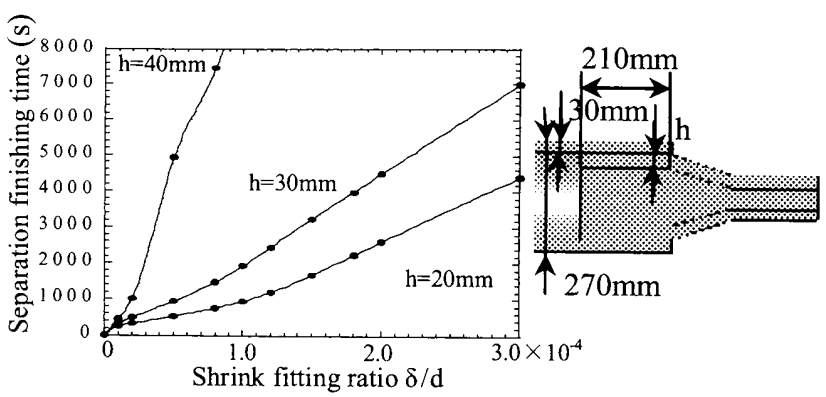

Fig. 6 Time vs. $\delta / \mathrm{d}$ when $\mathrm{h}=20 \mathrm{~mm}, 30 \mathrm{~mm}, 40 \mathrm{~mm}$

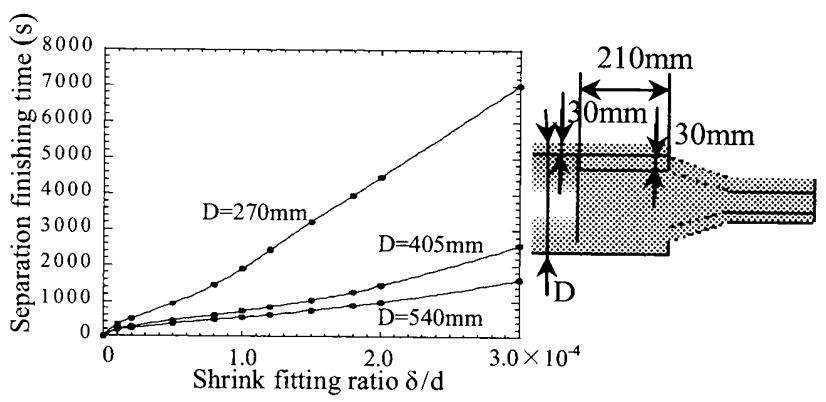

Fig. 7 Time vs. $\delta / d$ when $D=270 \mathrm{~mm}, 405 \mathrm{~mm}, 540 \mathrm{~mm}$

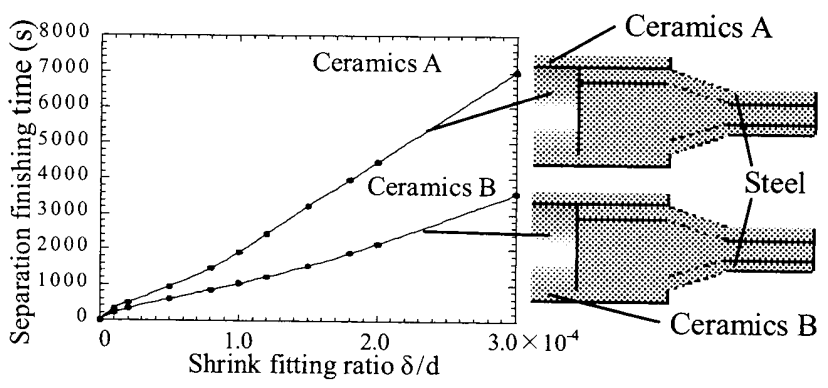

Fig. 8 Time vs. $\delta / d$ when Ceramics A sleeve, Ceramics B sleeve

\section{文 献}

(1) Tsuyunaru, M., Noda, N., Hendra., and Takase, Y., "Maximum Stress for Shrink Fitting System Used for Ceramics Conveying Rollers", Transactions of the Japan Society of Mechanical Engineering, Vol.74, No.743 (2008), pp.919-925 (in Japanese).

(2) Iwata, T. and Mori, H., "Material Choice for Hot Run Table Roller", Plant Engineer, Vol.15, No.6 (1983), pp.55-59 (in Japanese)

(3) Torii, K., "Heat Transfer Across the Solid Interface Governed by its Microscopic Surface-Structure -Interface between Macro-and Micro-Mechanics", The Japan Society of Mechanical Engineers, Vol.96, No.892 (1993), pp.198-203 (in Japanese) .. 